\title{
Digitizing and Evaluating Quality Assurance Documents at English Department, Faculty of Humanities
}

\author{
Novalinda $^{1, *}$ Marliza Yeni ${ }^{1}$

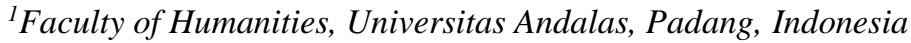 \\ *Corresponding author.Email: novalinda@hum.unand.ac.id
}

\begin{abstract}
This study aims to determine the level of satisfaction and effectiveness of digitizing quality assurance instruments such as the online form for thesis registration, proposal registration form, templates of some forms in English Department, Faculty of Humanities, Andalas University. The survey was conducted to the lecturers and students of English Departments. The survey covered ease of access, ease of understanding the narration or text, time efficiency, officially efficiency and so on. The results of the survey showed that most of the students and the lecturers were satisfied with the digitizing of some documents and forms. The respondents also give some suggestions to digitize any other documents and forms which are not being digitized yet. Besides, the survey also showed that 5 students out of 48 and 3 lecturers out of 23 said that the digitization still lack of socialization.
\end{abstract}

Keywords: digitizing, evaluating, quality assurance

\section{INTRODUCTION}

Quality Control Circle (GKM) is a group of people who work together and carry out activities periodically to strive for quality control by identifying, analyzing and taking action to solve problems faced at work. Basically, the main tasks and functions of GKM is to carry out the quality assurance process in an agency or institution. A university which is an institution of higher education consists of various faculties and study programs. Quality assurance at the tertiary level or at the university level is carried out by the Lembaga Pengembangan Pendidikan dan Penjaminan Mutu (Institute for Educational Development and Quality Assurance), while at the faculty level it is carried out by Badan Penjaminan Mutu (BAPEM) or the Quality Assurance Agency. BAPEM is responsible to make a planning, implementing, coordinating, monitoring, evaluating, controlling, and improving the Internal Quality Assurance Standards (SPMI) at the faculty level. At the department level, it is known as GKM (Quality Control Circle). GKM is a quality assurance unit which responsible for implementing, coordinating, monitoring, evaluating, and controlling the quality of the implementation of learning at the department/study program level [1]. English Department as one of the departments under the Faculty of Humanities also carries out quality assurance activities. At the study program level, the Quality
Control Circle carries out a quality assurance process related to monitoring and evaluation of various student services, lecturer performance, conducting analysis, making reports and providing recommendations for continuous improvement from the implementation of lecture activities and other activities related to students and lecturers. In addition, GKM is also tasked with compiling standard operating procedures at the study program level and ensuring that all SOPs that have been made can be implemented properly.

In accordance with the demands of accreditation, both old and new versions, each study program must carry out many surveys related to student's satisfaction, lecturers, graduate user, partners and collaboration partners to find out the extent of services that have been provided by the study program to students such as teaching methods, completeness of teaching materials, amount of face to face, assessment methods and so on to produce output that meets the standards of the world of work. In addition, evaluation of the various activities that have been taking place is also very necessary to determine the shortcomings or weaknesses of the program and then plan their repairs. To get maximum results, the study program needs to prepare and compile the survey instruments maximally, so that they can be analyzed to determine the advantages and disadvantages of the study program. In the future, the study program can take corrective steps for things 
that are deemed unsatisfactory and maintain those that are satisfactory.

\subsection{Related Literatures}

A survey is research techniques by giving clear boundaries to the data; investigation; review [2]. Structured questions are called questionnaires. The questionnaire contains questions that will be given to respondents to measure variables, the relationship between existing variables, and can be in the form of experiences and opinions of respondents. The survey method is usually used to obtain data from a certain natural place, but the researcher performs treatment in data collection (questionnaires, tests, interviews, and so on), the treatment given is not the same in the experiment [3].

To maximize the work of the Quality Control Circle at the study program level, concrete steps are needed so that it can be more efficient in terms of time, coverage, and implementation. One of the ways to conduct surveys and evaluations quickly and efficiently is by digitizing all questionnaires related to study programs. According to [2], digitization is the process of giving or using a digital system. Meanwhile, according to [4] digitization is the process of converting graphic information available on paper to digital format. In the process of digitizing it requires time, effort, money, and requires experts who master the techniques.

According to [5] Online surveys have several advantages compared to non-online surveys. These advantages include:

- It can be quickly disseminated to respondents via a link.

- It can reach a large number of online respondents.

- The summary presentation and display of results can be obtained in real-time through existing features in the software or application used.

- It can save printing costs and transportation costs to reach respondents.

- It can reduce the error rate in data organization.

- The respondents have more time flexibility to respond to surveys.

- The respondents feel more secure in their confidentiality because they can respond anonymously and do not need to face researchers directly.

\subsection{Form and Document}

The word form comes from Dutch, namely formulier, which means a paper containing several formal questions that must be filled in. Form text is a sheet in the form of a card or paper of a certain size which contains data or information that is fixed in nature and also some other non- permanent parts. Another meaning according to the [2] (Indonesian Language Official Dictionary) the form text is a paper that has formatted space and must be filled in by the user.

Form has many functions such as to find an information, to collect the data, to record the transaction or as a tool of communication. Through form we can find and collect any information we need for our research or another purposes. In university we use form as the tool for registration, asking our needs or to support our research.

As well as form documents also plays an important role in one institution. Documents are needed for every activity we do such as letter of decree, letter of assignment, invitation, etc. According to [3] document is written or printed letter that can be used as proof of information (such as birth certificates, marriage certificates, agreement letters); printed articles or essays sent by post; sound recordings, pictures in films, etc. which can be used as evidence for information.

\section{METHODS}

This research applied qualitative and quantitative methods. Qualitative research is an inquiry strategy that emphasizes the search for meaning, understanding, concepts, characteristics, symptoms, symbols and descriptions of a phenomenon; focused and multi method, natural and holistic; prioritizing quality, using several ways, and presented in a narrative. From the other side and in simple terms it can be said that the purpose of qualitative research is to find answers to a phenomenon or question through the application of scientific procedures systematically using a qualitative approach [6].

According to [3] Qualitative research method is called a new method, because of its recent popularity. It is called post-positivistic because it is based on the philosophy of post-positivism. This method is also called an artistic method, because research has less patterned, and is called an interpretive method because the research data is more concerned with the interpretation of the data found in the field.

Qualitative research methods are often called naturalistic research methods because the research is carried out in natural conditions; it is also called the ethnographic method, because initially this method was more widely used for research in the field of cultural anthropology; referred to as a qualitative method, because the data collected and analysis is more qualitative in nature. 
Meanwhile Quantitative research is a process of finding knowledge using data in the form of numbers as a tool to analyze information about what you want to know [7].

This research adopted two methods namely qualitative and quantitative since this research is aimed to find out the effectiveness and satisfaction of digitizing department's documents and forms then find the number of the respondents who response for strongly agree, agree, do not know, disagree and strongly disagree on each item being questioned in the survey.

The technique used in collecting the data is an online survey. The researcher conducted a survey using an online system and then the data obtained from the questionnaire was analyzed and narrated. The speakers in this study were all alumni of the English Department, partners and stakeholders from the English Department. In this study, data analysis was carried out by describing the survey results obtained to obtain service satisfaction results for students, lecturer performance and others.

The writer used Likert Scale in some questions in the survey [8]. This scale is used to measure the attitude and opinion of the respondents. With this Likert scale, respondents are asked to complete a questionnaire which requires them to indicate their level of agreement with a series of questions. The questions or statements used in this research are usually referred to as research variables and are determined specifically by the researcher

\section{RESULT AND DISCUSSION}

\subsection{Survey of Lecturers}

The survey related to the advantages of digitalization on department's documents and form was done to the lecturers and the students. The first survey was done to the lecturers as the user of these documents and forms.

In general, all English Department lecturers who filled out the satisfaction questionnaire of feel satisfied with the document digitization process that ha $\mathrm{d}$ been carried out. As can be seen in table 1, the positive answers are in the form of strongly agree and agree to all the questions surveyed points are above $75 \%$. The negative answer in the form of "disagree" was only found on four questions and not more than $15 \%$ of the total participants. In addition, there are still doubtful answers to the three survey questions but the number is also small, at no more than $15 \%$.

Table 1. Recapitulation of Lecturer Satisfaction Survey Results on Document Digitization

\begin{tabular}{|c|l|c|c|c|c|c|}
\hline $\begin{array}{c}\text { Question's } \\
\text { Number }\end{array}$ & \multicolumn{1}{|c|}{ Statements } & SA & A & DK & DA & SDA \\
\hline 1 & Ease of access & 42.9 & 57.1 & 0 & 0 & 0 \\
\hline 2 & Ease of Understanding & 28.6 & 50 & 7.1 & 14.3 & 0 \\
\hline 3 & The Narration is easy to be understood & 35.7 & 57.1 & 0 & 7.1 & 0 \\
\hline 4 & Time Efficiency & 64.3 & 35.7 & 0 & 0 & 0 \\
\hline 5 & Ease of official efficiency & 64.3 & 35.7 & 0 & 0 & 0 \\
\hline 6 & Save the paper & 100 & 0 & 0 & 0 & 0 \\
\hline 7 & Facilitate the work of lecturers & 64.3 & 35.7 & 0 & 0 & 0 \\
\hline 8 & $\begin{array}{l}\text { Make it easy to get proof of } \\
\text { performance }\end{array}$ & 71.4 & 28.6 & 0 & 0 & 0 \\
\hline 9 & $\begin{array}{l}\text { The socialization was carried out by the } \\
\text { department }\end{array}$ & 28.6 & 71.4 & 0 & 0 & 0 \\
\hline 10 & There is a complaint mechanism & 21.4 & 57.1 & 14.3 & 7.1 & 0 \\
\hline 11 & Document digitization is complete & 28.6 & 57.1 & 7.2 & 7.1 & 0 \\
\hline
\end{tabular}

Table 1 also shows that most of the lecturers agree with the first, second, and third questions that investigate the level of ease of accessing these digital documents (Figure 1), the clarity of the document editor (Figure 3), and the ease and clarity of the filling procedure (Figure 2). Although not all of them gave "very positive" answers, just 'agree' answers which on average are above $50 \%$ on the three points have shown recognition that the Department has carried out the digitization procedure properly in an easy-to- understand instruction format and understandable procedures.

The success of providing a good digitalization program implementation process has also proven to have implications that are highly appreciated by lecturers, as illustrated by the results of their responses to statements number five to number eight. All of these statements are classified as statements that investigate the success and usefulness of this document digitization program for lecturers in terms 
of time efficiency, ease of official correspondence, paper savings, ease of work, and the ease of obtaining evidence of their performance. The responses of the lecturers participating in the questionnaire to all of these statements proved positive. Not one of the lecturers gave a negative or hesitant response to the benefits of this program in the various aspects investigated. In contrast to the first classification, the majority of the answers given were on the very positive side, namely "strongly agree".

Although the program implementation process and its output is proved successful in satisfying the lecturers the provision of complaint collection mechanisms and the completeness of documents that had been digitized still needed to be improved. The success of the socialization of this program by the Department to the lecturers needs to be accompanied by the provision of a complaint mechanism and troubleshooting/problem anticipation that can be easily accessed by all lecturers so that all problems that may be faced in matters related to digitizing documents can be resolved more effectively.

The next survey was conducted to the students of English Departments, especially 2015, 2016, and 2017 generation since these students often take advantage of the documents and online forms provided by the department such as proposal seminar registration, thesis registration, template of some forms and another documents which are needed by the students during their studies in English Department, Faculty of Humanities, Andalas University.

The results of the survey which were followed by 47 students of English Department regarding to the digitalize document were not much different when comparing to the results of the survey to the lecturers. In general, student responses to each survey item showed more positive results than lecturers with an average of $80 \%$ give positive answers on ten items and the last item (number 11) which received $61.7 \%$ responses strongly agree and agree. A striking difference is seen in the high number of students' doubts in giving answers. Meanwhile, the negative answer is only in the "disagree" option and on average it is on each of the points surveyed. This is because socialization to students is more frequent than to lecturers. Besides, students often ask if there are things they do not understand regarding these documents and online forms.

\subsection{Survey of Students}

Table 2. Recapitulation of Student Satisfaction Survey Results on Document Digitization

\begin{tabular}{|c|l|c|c|c|c|c|}
\hline $\begin{array}{c}\text { Question's } \\
\text { Number }\end{array}$ & \multicolumn{1}{|c|}{ The Statements } & SA & A & DK & DA & SDA \\
\hline 1 & Ease of access & 25.5 & 59.6 & 6.4 & 8.5 & 0 \\
\hline 2 & Ease of Understanding & 23.4 & 63.8 & 8.5 & 4.3 & 0 \\
\hline 3 & The Narration is easy to be understood & 19.1 & 63.8 & 12.8 & 4.3 & 0 \\
\hline 4 & Time Efficiency & 36.2 & 57.4 & 4.5 & 1.9 & 0 \\
\hline 5 & Ease of official efficiency & 40.4 & 51.1 & 4 & 4.5 & 0 \\
\hline 6 & Save the paper & 76.6 & 23.4 & 0 & 0 & 0 \\
\hline 7 & Ease the Students & 42.6 & 48.9 & 4 & 4.5 & 0 \\
\hline 8 & Ease to get the documents/forms & 27.7 & 59.6 & 8.5 & 4.2 & 0 \\
\hline 9 & Socialization & 17 & 66 & 10 & 7 & 0 \\
\hline 10 & $\begin{array}{l}\text { The availability of complain } \\
\text { mechanism }\end{array}$ & 23.4 & 57.4 & 8.6 & 10.6 & 0 \\
\hline 11 & The completeness of documents & 17 & 44.7 & 25.5 & 12.8 & 0 \\
\hline
\end{tabular}

As shown in Table 2, the majority of students gave a more positive assessment than lecturers in terms of the process of implementing this document digitization program. Statements one, two, and three received positive responses above $59 \%$, slightly above the lecturers' answers which were no more than $57.1 \%$. However, students did not seem too sure about the ease of access, editorial clarity, and the ease / clarity of the procedure for filling out the department's digital documents. This doubt is also reinforced by high number of responses for "don't know|" answer to these three question compared to the number "disagree".

Therefore, although the student response is considered very positive, it should also be noted that there are students who have difficulty accessing and following instructions for using digital documents in their activities in the department.

This doubt also seems to be reflected in students' answers to the effects of digitizing this department's documents. Students 'agree' answers regarding the problems of time efficiency, ease of academic administration, paper saving, ease of carrying out academic activities, and ease of obtaining evidence of their activities, being in the $58-60 \%$ range seems to reinforce at first glance any doubt about the benefits of digitizing this department's documents for them. Although time efficiency and paper savings appear to be undeniable positive benefits, there were still 
students who answered that they did not know or did not agree with these benefits.

Similar to the responses given by the lecturers, points regarding socialization and the mechanism for anticipating problems related to digital documents received higher neutral (don't know) and negative (disagree) responses. The highest level of student confidence (strongly agreed) with the socialization process carried out by Head of English Department was at $66 \%$ while the majority of students also acknowledged that the complaint mechanism and problem solving related to digital documents had been submitted. Although the majority of students also admitted that the documents digitizing the department were complete, there were also $22.5 \%$ "don't know" answers and $12.8 \%$ "disagree" answers regarding this completeness. The accumulated number of these two items $(35.3 \%)$ can be used as a warning sign for departments to re-evaluate the completeness of this digital document as well as to check if the cause is also related to socialization issues that may be inadequate for a small number of students.

\section{CONCLUSION}

After doing the survey on the effects of digitalization of quality assurance instruments in English Departments, Faculty of Humanities, Andalas University, the researcher found that 20 lecturers and 43 students give positive response for some items such as the easiness to access the documents and form, easiness in understanding the text, time efficiency, paperless and the socialization. Meanwhile the small numbers of negative response come from the completeness of documents and forms and complaint mechanism. By this result the departments need to re- evaluate the completeness of documents and to socialize it continuously.

\section{ACKNOWLEDGMENTS}

Thank you to the Rector, Vice Rectors, head of LP3M and Staffs, Dean and Vice Dean of Faculty of Humanities, Head of English Department of Andalas University for giving us chance and support to do this research. Hope it can help the departments to be better in the future.

\section{REFERENCES}

[1] Tim Penyusun. 2020. Keputusan Dekan Fakultas Ilmu Budaya Universitas Andalas. Padang: Fakultas Ilmu Budaya. [2] Kamus Besar Bahasa Indonesia Online

[3] Sugiyono. (2017). Metode Penelitian Kuantitatif, Kualitatif, dan R\&D. Bandung: Alfabeta, CV.

[4] Khomsin, 2004. Buku Ajar Pemetaan Digital. Surabaya. Program Studi Teknik Geodesi FTSPITS.

[5] Setiawan, T.P, 2012. Survei Online: Panduan Praktis Bagi Praktisi dan Akademisi, PT Elex Media Komputindo,

[6] Yusuf, A.M, 2016. Metode Penelitian Kualitatif. Prenada Media.

[7] Kasiram, Mohammad. 2008. Metode Penelitian Kualitatif dan Kuantitatif. UIN Malang Pers.

[8] Likert, R. 1961. New Patterns of Management. Auckland: Mc. Graw Hill International Book Company. 